\title{
Expression of Serpin B9 as a Prognostic Factor of Colorectal Cancer
}

\author{
ONDREJ VYCITAL ${ }^{1,2}$, PAVEL PITULE $^{2}$, PETR HOSEK ${ }^{2}$, TOMAS KRIZ ${ }^{2}$, \\ VLADISLAV TRESKA ${ }^{1}$ and VACLAV LISKA ${ }^{1,2}$ \\ ${ }^{1}$ Department of Surgery, Charles University, University Hospital Pilsen, Pilsen, Czech Republic; \\ ${ }^{2}$ Biomedical Center, Faculty of Medicine in Pilsen, Charles University, Pilsen, Czech Republic; \\ ${ }^{3}$ Faculty of Medicine in Pilsen, Charles University, Pilsen, Czech Republic
}

\begin{abstract}
Background/Aim: Treatment of colorectal cancer (CRC) does not reflect immune interactions between tumours and macro-organisms. Serpin B9 is known as an inhibitor of Granzyme B. The aim of this study was to evaluate the impact of the expression of Serpin B9 in CRC and healthy colon tissue on prognosis. Patients and Methods: This retrospective study included 74 CRC patients in all stages. Analysis of gene expression was performed with quantitative polymerase chain reaction with reverse transcription using specific primers and master mix Xceed qPCR SG. Expression was normalized to the reference genes GAPDH, ACTB, and PSMC. Results: Increased expression of Serpin B9 in healthy tissue was significantly associated with longer overall survival (OS). This association was found both in all patients and in the group of patients with distant metastases. Conclusion: The presented results support previous evidence of positive influence of the interaction between immune system and tumour on the prognosis of $C R C$.
\end{abstract}

Colorectal carcinoma (CRC) is a severe health and social issue occurring at high incidence rates (1). Recent approaches to treatment of CRC are based on the staging according to the Union Internationale Contre le Cancer (UICC), which integrates the TNM classification with other risk factors However, these risk factors do not reflect immune interactions between tumours and macro-organisms (2).

Serpin B9 is known as an endogenous inhibitor of Granzyme B in humans, which protects against the cytotoxic granule leakage. At the molecular level, Serpin B9 inhibits

Correspondence to: Ondrej Vycital, Department of Surgery, Charles University, Medical School and Teaching Hospital Pilsen, U Jam 17, Pilsen 323 00, Czech Republic. Tel: +420 776817904, e-mail: vycitalo@fnplzen.cz

Key Words: Colorectal cancer, visceral surgery, immunosurveillance, serpin B9, prognostic factor. the cytolytic function of Granzyme B by forming a reversible Michaelis complex (3). Serpin B9 is secreted from cytotoxic lymphocytes (4), smooth muscle cells, endothelial cells, and hepatocytes. Immunoprivileged cells, i.e., trophoblast cells, Sertoli cells, granulosa cells and cells of the eye lens produce this inhibitor as well. The proposed function of Serpin B9 is the protection against cytotoxic immunity (5). In malignant cells, Serpin B9 production has been observed in breast cell carcinoma (6), melanomas (7), cervical cancer (8) and in leukemia cells (9). In addition, CRC cells also produce Serpin B9 (8). Expression of Serpin B9 is one of the ways by which malignant cells avoid cytotoxic lymphocytemediated killing (10). Serpin B9 expression in rectal cancer tissue has been suggested as a negative predictive factor of neoadjuvant chemoradiotherapy $(11,12)$.

We have previously shown that increased expression of Serpin B9 in colorectal cancer cells is associated with regional lymph node metastases (13).

The aim of the present study was to evaluate the impact of Serpin B9 expression in CRC and healthy colon tissue on the progression and prognosis of CRC. The secondary target of this study was to confirm previous results showing that increased expression of Serpin B9 in colorectal cancer cells is associated with regional lymph node metastases.

\section{Patients and Methods}

Patients. This monocentric retrospective study included 74 CRC patients, 10 patients were in stage I, 20 patients in stage II, 35 patients in stage III and 9 patients in stage IV. This study was conducted at the Department of Surgery, Charles University, Medical School and Teaching Hospital Pilsen between 2013 and 2016. A total of 36 females (median age 68.86 years, min 49.27 and max 89.81 years) and 38 males (median age 67.36 years, min 38.74 and 88.14 years), who underwent surgical therapy for CRC were included in the study. Exclusion criteria were: inflammatory bowel disease, familiar adenomatosis, insufficient number of examined lymph nodes in resected bowel or rectum (less than 13) and or previous malignancy. Patients presenting tumour rupture, acute bleeding and ileus were also not included. The followup of patients occurred during standard dispensarization. 
Statistics. Differences in the expression of serpin B9 between healthy tissue and tumour were analysed using Wilcoxon signedrank test. Mann-Whitney $U$-test was used to compare Serpin B9 expression (in healthy and tumour tissue) between patients with and without regional lymph node metastasis. Differences in Serpin B9 expression between UICC stages were assessed using KruskalWallis ANOVA. The association between Serpin B9 expression and overall survival (OS) or disease-free interval (DFI) was investigated using univariable Cox proportional hazards model with subsequent stratification by median expression and visualisation by KaplanMeier plots. The analysis was performed using STATISTICA software (version 12, Cz, StatSoft, Inc. 2013, Prague, Czech Republic).

\section{Gene expression analysis}

Primer design. Oligonucleotide primers for quantitative real-time polymerase chain reaction (qPCR) were designed using Primer-3 software (14). All primers span exon-exon boundaries and their specificity was tested in silico by BLAST (15). Reference genes $G A P D H, A C T B$ and PSMC4 were previously tested in our laboratory and were used for normalization of Serpin B9 expression. Optimal annealing temperature and specificity of reactions were evaluated by $\mathrm{Cq}$ values analysis, melt curve analysis and agarose gel electrophoresis.

RNA isolation. Snap-frozen samples of tumor tissue and macroscopically non-malignant mucosa were grounded in liquid nitrogen and total RNA was isolated by TRI Reagent@RT (Molecular Research Center, Inc., Cincinnati, OH, USA) according to manufacturer's protocol. RNA was resuspended in nuclease-free water and stored at $-80^{\circ} \mathrm{C}$. RNA concentration (absorbance at 260 $\mathrm{nm})$ and purity $(230 \mathrm{~nm} / 260 \mathrm{~nm}$ absorbance ratio) were measured with the Tecan Infinite M200 (Tecan Trading AG, Männedorf, Switzerland) using NanoQuant settings. RNA integrity was examined by agarose gel electrophoresis.

Reverse transcription. Reverse transcription of RNA was performed using the RevertAid First Strand cDNA Synthesis Kit (ThermoFisher Scientific, Waltham, USA) in $20 \mu \mathrm{l}$ reaction. Five hundred ng of total RNA were first treated for 5 min with DNase I (Top-Bio, Vestec, Czech Republic) to remove potential traces of genomic DNA. Mixture of random hexamers and oligo(dT) 18 primers, each at a $2.5 \mu \mathrm{M}$ final concentration, were used for reverse transcription. Reaction conditions were set according to the manufacturer's protocol. The quality of cDNA and the possibility of DNA contamination were examined by PCR in the absence of reverse transcriptase or cDNA samples (GAPDH primers, 40 cycles) and agarose gel electrophoresis.

Quantitative real-time PCR. Xceed qPCR SG master mix (IAB, Prague, Czech Republic) was used for qPCR. cDNA was diluted to $0.5 \mathrm{ng} / \mu \mathrm{l}$ and $4.75 \mu \mathrm{l}$ of cDNA was mixed with $0.25 \mu \mathrm{l}$ of gene specific primers and $5 \mu \mathrm{l}$ of master mix in a final volume of $10 \mu \mathrm{l}$ per reaction. Reference genes were analyzed in duplicate and Serpin B9 in triplicate using the CFX96 real-time PCR instrument (Biorad, Hercules, CA, USA). The following reaction conditions were used: initial denaturation at $95^{\circ} \mathrm{C}$ for $5 \mathrm{~min}, 45$ two-step cycles with denaturation at $95^{\circ} \mathrm{C}$ for $10 \mathrm{sec}$ and annealing and extension at $62^{\circ} \mathrm{C}$ for $30 \mathrm{sec}$, and finally melting curve analysis with denaturation at $95^{\circ} \mathrm{C}$ for $15 \mathrm{sec}$ followed by continuous measurement of fluorescence between $60^{\circ} \mathrm{C}$ and $90^{\circ} \mathrm{C}$ with the step of $0.5^{\circ} \mathrm{C}$. Data were analyzed using Biorad CFX Manager ${ }^{\mathrm{TM}}$ software and quality checked $\mathrm{Cq}$ values were used for statistical analysis.

\section{Results}

No significant differences were found in the expression of Serpin B9 between healthy and tumorous tissues (Figure 1). There were also no significant differences in Serpin B9 expression between groups UICC I, II, II and IV (Figure 2). Spearman test showed a non-significant perceptible trend in the expression of Serpin B9 in tumorous tissue with increasing UICC stage $(p=0.075)$. We did not find any significant differences between groups of patients with and without metastases in regional lymph nodes (N0 versus N1 and N2 lymph node status).

Increased expression of Serpin B9 in healthy tissue was significantly associated with longer OS in all patients ( $p=0.0023$, Figure 3), as well as in the group of patients with distant metastases ( $p=0.0169$, Figure 4 ). Regarding DFI, no relationship between disease progression and Serpin B9 expression in either healthy or tumour tissue was observed.

\section{Discussion}

Based on the previous results of our immunohistochemical study in CRC (13), an increased Serpin B9 expression was expected to be found in the tumour tissue of UICC III (with lymph node metastasis) patients in comparison with tumour tissues of group UICC II (without lymph node metastasis). Surprisingly, this was not the case, probably because a whole spectrum of cells from the tumour tissue were analysed together in the expression assay, and not only adenocarcinoma cells. It is known that tumour infiltrating lymphocytes produce Serpin B9 (4). The presence of tumour infiltrating lymphocytes has been revealed to be an important prognostic factor $(16,17)$ that could influence the results. It remains unclear if there is any causality in the association of Serpin B9 expression in non-tumorous colon tissue and OS. Information from non-tumorous tissue samples can indicate its suitability and its impact on prognosis (18).

Because we showed significantly increased expression of Serpin B9 in non-tumorous tissue in the group of patients with distant metastases and better OS, it would be interesting to investigate the predictive value of serpin $\mathrm{B} 9$ expression in non -tumorous tissue on the effect of oncological treatment. Currently, there are data only about the influence of Serpin B9 expression in rectal cancer cells on the response to neoadjuvant chemoradiotherapy $(11,12)$. We did not evaluate expression of serpin B9 as a predictive factor of oncological treatment outcomes because of the small number of patients in the UICC IV group with increased expression of Serpin B9 (9 patients in the whole group). 


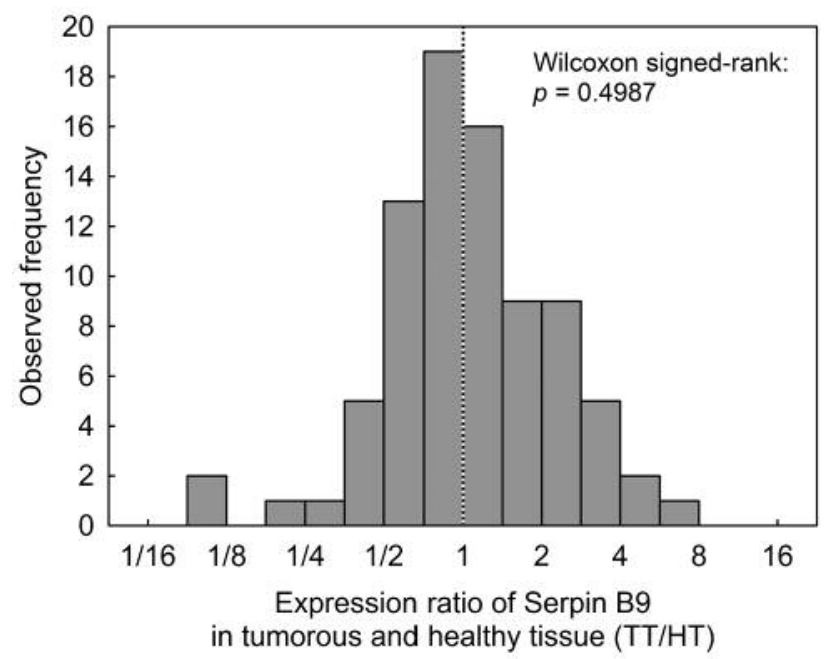

Figure 1. No significant differences were found in Serpin B9 expression between healthy and tumorous tissues.

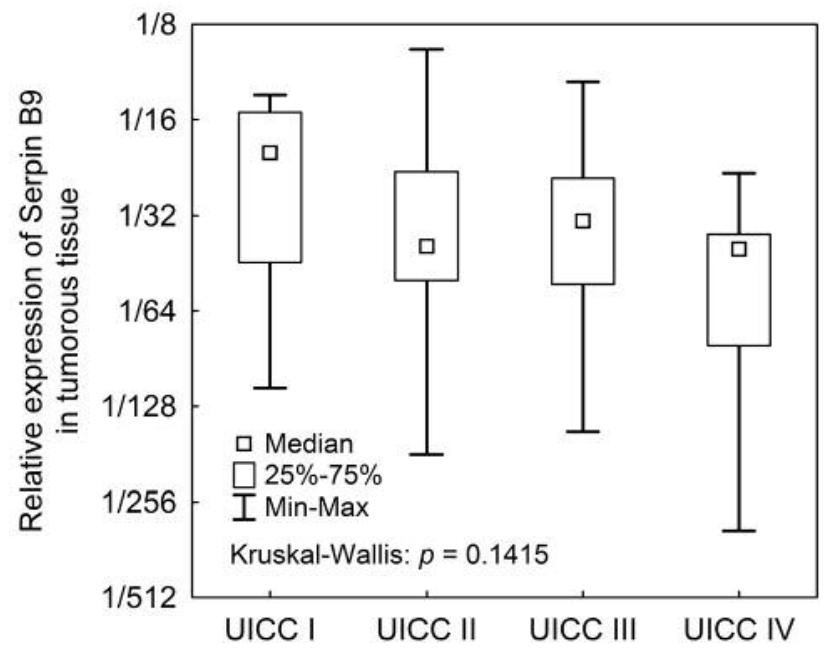

Figure 2. No significant differences in Serpin B9 expression were observed between the cohorts UICC I, UICC II, UICC III and UICC IV in tumorous tissue.

\section{Conclusion}

The present results support previous evidence indicating a positive influence of the interaction between immune system and tumor on the prognosis of CRC as exemplified by the effect of the expression of granzyme B inhibor - Serpin B9. On the other hand, the mechanism by which Serpin B9 influences the prognosis of $\mathrm{CRC}$ remains unclear. However, there is a plethora of prognostic factors available for CRC and it is now important to analyze them in order to select patients who will benefit from intensive oncological treatment.

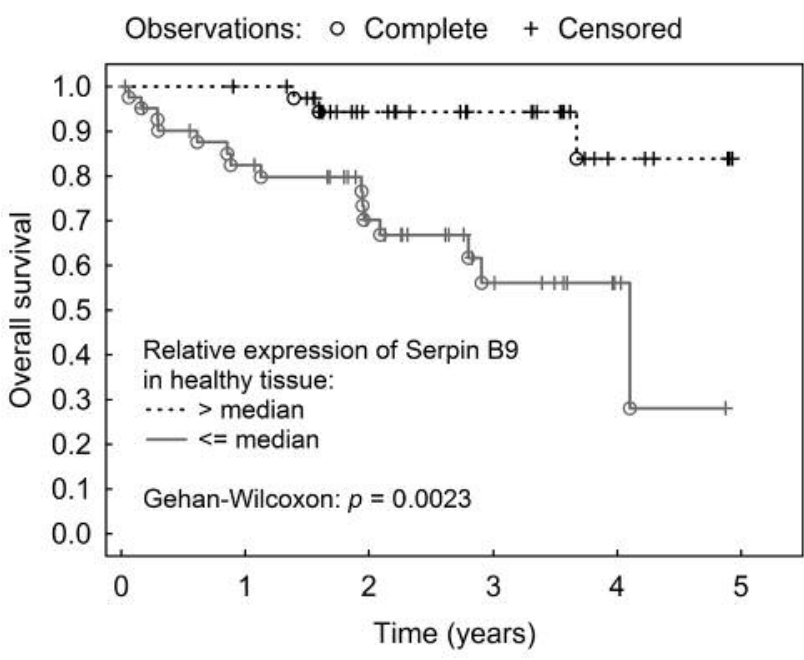

Figure 3. Positive effect of increased Serpin B9 expression in healthy tissue on OS of all patients in the study.

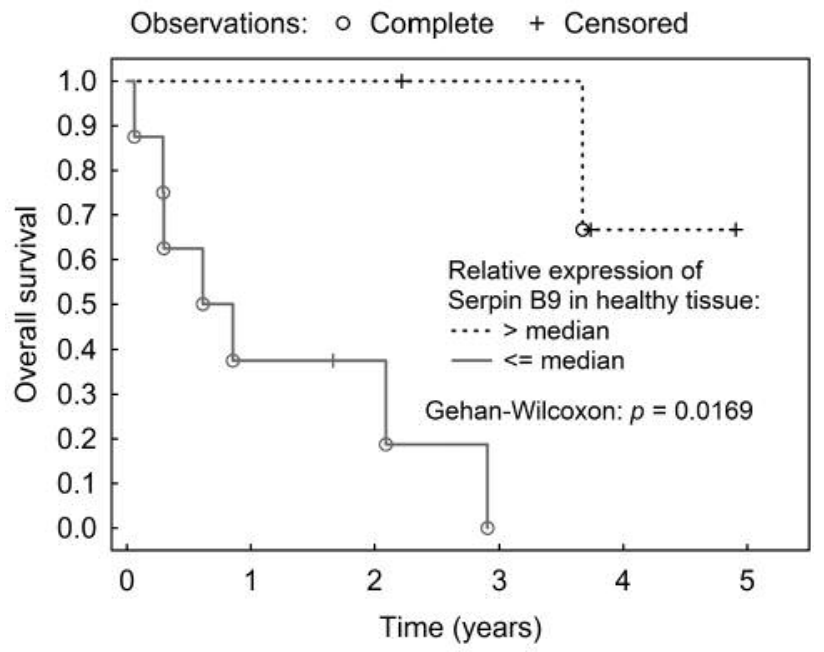

Figure 4. Positive effect of increased Serpin B9 expression in healthy tissue on $\mathrm{OS}$ in the group of patients with distant metastases.

\section{Conflicts of Interest}

The Authors dcclare no conflicts of interest regarding this study.

\section{Authors' Contributions}

Ondrej Vycital - corresponding author, methodology, data and specimen collection, data analysis, data curation, writing - original draft; Pavel Pitule - gene expression analysis; Tomas Kriz - data collection; Hosek Petr - data analysis, data curation, performance of the statistical analysis; Liskav Vaclav - supervision, validation, investigation; Treska Vladislav - supervision, validation. 


\section{Acknowledgements}

Funding: This study was supported by the National Sustainability Program I (NPU I; No. LO1503) provided by the Ministry of Education, Youth and Sports of the Czech Republic and by Grant Agency of the Czech Republic (GACR 18-09709S) and by Charles University Research Centre program UNCE/MED/006 "University Center of Clinical and Experimental Liver Surgery".

\section{References}

1 Ferlay J, Soerjomataram I, Dikshit R, Eser S, Mathers C, Rebelo M, Parkin DM, Forman D and Bray F: Cancer incidence and mortality worldwide: Sources, methods and major patterns in GLOBOCAN 2012. Int J Cancer 136(5), 2015. PMID: 25220842. DOI: $10.1002 /$ ijc. 29210

2 Sobin LH, Gospodarowicz MK and Wittekind CH: TNM classification of malignant tumours. 7th ed: Hoboken, NJ: WileyBlackwell, 2010. PMID: 20593484. DOI: 10.1002/path.2729

3 Losasso V, Schiffer S, Barth S and Carloni P: Design of human granzyme B variants resistant to serpin B9. Proteins 80(11): 2514-2522, 2012. PMID: 22733450. DOI: 10.1002/prot.24133

4 Sun J, Bird CH, Sutton V, McDonald L, Coughlin PB, De Jong TA, Trapani JA and Bird PI: A cytosolic granzyme B inhibitor related to the viral apoptotic regulator cytokine response modifier $\mathrm{A}$ is present in cytotoxic lymphocytes. J Biol Chem 271(44): 2780227809, 1996. PMID: 8910377. DOI: 10.1074/jbc.271.44.27802

5 Bladergroen BA, Strik MC, Bovenschen N, van Berkum O, Scheffer GL, Meijer CJ, Hack CE and Kummer JA:The granzyme B inhibitor, protease inhibitor 9, is mainly expressed by dendritic cells and at immune-privileged sites. J Immunol 5: 3218-3225, 2001. PMID: 11207275. DOI: 10.4049/jimmunol.166.5.3218

6 Lauricella M, Carlisi D, Giuliano M, Calvaruso G, Cernigliaro C, Vento R and D'Anneo A: The analysis of estrogen receptor- $\alpha$ positive breast cancer stem-like cells unveils a high expression of the serpin proteinase inhibitor PI-9: Possible regulatory mechanisms. Int J Oncol 49(1): 352-360, 2016. PMID: 27121069. DOI: $10.3892 /$ ijo.2016.3495

7 Irmler M, Thome M, Hahne M, Schneider P, Hofmann K, Steiner V, Bodmer JL, Schröter M, Burns K, Mattmann C, Rimoldi D, French LE and Tschopp J: Inhibition of death receptor signals by cellular FLIP. Nature 388(6638): 190-195, 1997. PMID: 9217161 . DOI: $10.1038 / 40657$

8 Medema JP, de Jong J, Peltenburg LT, Verdegaal EM, Gorter A, Bres SA, Franken KL, Hahne M, Albar JP, Melief CJ and Offringa R: Blockade of the granzyme B/perforin pathway through overexpression of the serine protease inhibitor PI-9/SPI6 constitutes a mechanism for immune escape by tumors. Proc Nat Acad Sci 20: 11515-11520, 2001. PMID: 1156248. DOI: 10.1073/pnas.201398198

9 Fritsch K, Finke J and Grüllich C: Suppression of granzyme B activity and caspase-3 activation in leukaemia cells constitutively expressing the protease inhibitor 9: Ann Hematol Dec 92(12): 1603-1609, 2013. PMID: 23892923. DOI: 10.1007/s00277-013$1846-6$
10 de Koning PJ, Kummer JA, de Poot SA, Quadir R, Broekhuizen R, McGettrick AF, Higgins WJ, Devreese B, Worrall DM and Bovenschen N: Intracellular serine protease inhibitor SERPINB4 inhibits granzyme M-induced cell death. PLoS One 6(8): e22645, 2011. PMID: 21857942. DOI: 10.1371/journal.pone.0022645

11 Repetto O, De Re V, De Paoli A, Belluco C, Alessandrini L, Canzonieri $\mathrm{V}$ and Cannizzaro R: Identification of protein clusters predictive of tumor response in rectal cancer patients receiving neoadjuvant chemo-radiotherapy. Oncotarget 8(17): 28328-28341, 2017. PMID: 28423701. DOI: 10.18632/oncotarget.16053

12 Chauvin A and Boisvert FM: Clinical proteomics in colorectal cancer, a promising tool for improving personalised medicine. Proteomes 6(4), 2018. PMID: 30513835. DOI: 10.3390/ proteomes 6040049

13 Vycital O, Dubova M, Palek R, Hosek P, Branzovsky J, Treska $\mathrm{V}$, Daum $\mathrm{O}$ and Liska V: The impact of immune interaction on the metastatic infiltration of colorectal carcinoma to lymph nodes. Anticancer Res 38(7): 4159-4167, 2018. PMID: 29970545. DOI: 10.21873/anticanres.12709

14 Untergasser A, Cutcutache I, Koressaar T, Ye J, Faircloth BC, Remm $M$ and Rozen SG: Primer 3-new capabilities and interfaces. Nucleic Acids Res 40(15), 2012. PMID: 22730293. DOI: $10.1093 /$ nar/gks596

15 Altschul SF, Madden TL, Schäffer AA, Zhang J, Zhang Z, Miller $\mathrm{W}$ and Lipman DJ: Gapped BLAST and PSI-BLAST: a new generation of protein database search programs. Nucleic Acids Res 25(17): 3389-3402, 1997. PMID: 9254694. DOI: 10.1093/ nar/25.17.3389

16 Liska V, Vycital O, Daum O, Novak P, Treska V, Bruha J, Pitule $\mathrm{P}$ and Holubec L: Infiltration of colorectal carcinoma by S100+ dendritic cells and CD57+ lymphocytes as independent prognostic factors after radical surgical treatment. Anticancer Res 5: 2129-2132, 2012. PMID: 22593500.

17 Galon J, Costes A, Sanchez-Cabo F, Kirilovsky A, Mlecnik B, Lagorce-Pagès C, Tosolini M, Camus $\mathrm{M}$, Berger A, Wind $\mathrm{P}$, Zinzindohoué F, Bruneval P, Cugnenc PH, Trajanoski Z, Fridman WH and Pagès F: Type, density, and location of immune cells within human colorectal tumors predict clinical outcome. Science 313(5795): 1960-1964, 2006. PMID: 17008531. DOI: $10.1126 /$ science. 1129139

18 Thiele JA, Hosek P, Kralovcova E, Ostasov P, Liska V, Bruha J, Vycital O, Rosendorf J, Opattova A, Horak J, Kralickova M, Vodicka P and Pitule P: IncRNAs in non-malignant tissue have prognostic value in colorectal cancer. Int J Mol Sci Sep 19(9): 2672, 2018. PMID: 30205577. DOI: 10.3390/ijms 19092672

Received September 5, 2019 Revised September 24, 2019 Accepted September 30, 2019 